\title{
XXXV. On Mr. Fearn's Observations on external perception, \&c.
}

\section{T. Forster Esq.}

To cite this article: T. Forster Esq. (1815) XXXV. On Mr. Fearn's Observations on external perception, \&c. , Philosophical Magazine Series 1, 45:203, 193-194, DOI: $10.1080 / 14786441508638415$

To link to this article: http://dx.doi.org/10.1080/14786441508638415

里 Published online: 27 Jul 2009.

Submit your article to this journal

Џll Article views: 1

Q View related articles $๘$ 
difficult and the others more easy to decompose, the compounds of hydrogen corresponding with the first in the manner which I have explained, are the only ones which can be obtained, at least in the isolated state; and that those which correspond in the same manner with the less stable combinations of orygén are either impossible, or cannot exist but when united to a third body. According to this addition of four nolecules or of an entire particle of hydrogen to the number of the molecules of oxygen assumed by the different bodies in their most stable combinations with this last gas, we find six molecules of hydrogen when there are two of oxygen in these combinations, and eight when there are four.

The same considerations also lend us to foresee, according to the representative forms of their particles, what are the gases which water cannot absorb, but in very small quantity, by the simple interposition of some of their particles between those of water, and those which the same liquid is susceptible of absorbing in large quantities, and forming with them true combinations.

[To be coutinued.]

\section{On Mr. Fearne's Olserwatims on external Per- ception, \&ீc. By' T. Forster, Esq.}

\section{To $M r$, Tillock.}

SIR, IN a paper On external Perception, recently published in the Pamphleteer, by Mr. Fearne, he his maintained an opinion that our perception of external objects is not by means of the five senses alone, but that it is an ant of the minrl. As this doctrine, at least as expressed in the manner le has delivered it, is somewhat novel; and as it coincides with an opinion which has resulted from the last discoveries into the physiology and structure of the organs. of the brain, I am induced to point out to the metaphysical speculator the great similarity of opinions drawn from different sources, on a subject which has so frequently engaged the attention of philosophers. I do not proceed with $\mathrm{Mr}$. Fearne in all his reasonings throughout the course of his various metaphysical inquiries, but allucle specially to the opinion that the sensation of objects by means of the five external senses is not sufficient to produce the belief of the external existence of bodies. But I believe the perception of the external bodies to be the consequerce of an organic apparatus quite as material as the nerves of the five senses. In short, the organ of individuality, or that part of the front lobes of the brain alove the nose, in the midale aind inferior part of the forehead, is

Vol. 45. No. 203. March 1815. 
the cause of our belief of external bodies. This organ also excites the activity of the five senses, and thereby is active, by means of them, in producing the sensation of lodies, which it furthermore causes us to regard as external, individual, and existent, independent of our scnsations of them. I have long conceived, as I formerly mentioned, that there must exist some special faculty in the mind for this perception of individuality; but it was Dr. spurzheim who pointed out the seat of its organ. I recommend the study, therefore, of the structure and organic arrangeinent of the brain published by him and Gall, to all those who wish to see the material engines of the various functions of the nind. They will be really sumprised, if they follow up this course of anatomical and physiological studies attentively, at the great progress which has in so short a time been made in a science which has for ages been regarded as the most difficult and at the same time the most interesting in the world. The phrenology of Gall and Spurzheim has verified what Richerand hinted at as the ne plus ultra of physiology, when he anticipated a mode to solve the problem of the principles of the actions of animated beings; and, given the physical structure of any person, to find his moral and intellectual qualities.

The proofs that the aforesaid faculty of individuality resides in the particular organ ascribed to it, are founded on a series of ficts too numerous to be detailed here. I have fortunately had many cases both of the great as well as of the defective development of that organ, to confirm and put beyond all doubt in my nind the truth of the plysiology he has imputed to it. And $\dot{I}$ mention this apparent coincidence of opinion, to excite others to cxamine; as these very abstruse considerations, such as are contained in Mr. Fearne's work, are very liable to be misunderstood, and it becomes desirable to call forth and collect the different views of the philosophy of mind which they excite in people of different organizations.

Cambridge, March 11, 1815. Yours, \&ic.

Thomas Forster.

XXXVI. On the Pyramids of Egypt. Extracted from $D r$. Edward Daniel Clarke's Travels, Vol. III.*

PYRAMIDS OF DJIZA.

As we drew near the base of the principal pyramid, the effect of its prodigious magnitude, and the amusement caused in view-

* Dr Charke's account of the pyranids is by far the most philosophical and satistrictory of any that have been offered to the world on these interesting monuments of antiquity. Our readers, we arc confident, will he highly gratilied to lind it in our jages. 